\title{
The hospital ethical climate and its meaning in nursing work. A review of research results
}

\section{Klimat etyczny szpitala i jego znaczenie w pracy pielęgniarskiej. Przegląd wyników badań}

\author{
Magdalena Dziurka, Patrycja Ozdoba, Anna Jedynak, Beata Dobrowolska \\ Department of Management in Nursing, Faculty of Health Sciences, Medical University of Lublin, Lublin, Poland \\ Head of the Department: Beata Dobrowolska PhD, Associate Professor
}

Key words: ethical climate, hospital ethical climate survey, HECS, nurses.

Słowa kluczowe: klimat etyczny, skala klimatu etycznego szpitala, HECS, pielęgniarki.

\begin{abstract}
The ethical climate reflects the principles and guidelines of an organisation. A positive ethical climate is characterised by a common vision of caring for work, in which the therapeutic team members inform and support each other, and which meets the needs of patients and their families. The aim of this study was to analyse nursing research on the hospital's ethical climate conducted with the Hospital Ethical Climate Survey (HECS) and to analyse factors which correlate and are related to nurses' work. A critical review of the literature from 1995 to 2021 was conducted with the following keywords: ethical climate, hospital ethical climate survey, HECS, and nurses. The hospital ethical climate correlates with nurses' moral sensitivity/courage/distress, job satisfaction, job burnout, and ethical leadership. This makes it possible to monitor and assess elements of the organisation climate and how they influence nurses' professional performance. This in turn helps nursing managers to develop strategies to promote better working conditions for nurses, improve job satisfaction, and prevent intent to change their workplace.
\end{abstract}

\section{Streszczenie}

Klimat etyczny odzwierciedla zasady i wytyczne organizacji. Pozytywny klimat etyczny charakteryzuje się wspólną wizją troski o pracę, w której zespół terapeutyczny wzajemnie się informuje i wspiera, odpowiada na potrzeby pacjentów i ich rodzin. Celem pracy była analiza badań pielęgniarskich dotyczacych klimatu etycznego w szpitalu z zastosowaniem narzędzia badawczego Hospital Ethical Climate Survey (HECS), a także korelujących z nim czynników związanych z pracą pielęgniarek. Krytyczny przegląd dostępnego piśmiennictwa od 1995 do 2021 roku przeprowadzono według następujących słów kluczowych: klimat etyczny, badanie klimatu etycznego szpitala, HECS, pielęgniarki. Klimat etyczny szpitala koreluje m.in. z wrażliwością, odwagą, cierpieniem moralnym, satysfakcją z pracy, wypaleniem zawodowym, przywództwem etycznym. Umożliwia monitorowanie i ocenę elementów klimatu organizacyjnego oraz ich wpływu na wyniki zawodowe pielęgniarki. To natomiast daje menadżerom pielęgniarstwa narzędzia pozwalające na wdrożenie strategii promujących lepsze warunki pracy pielęgniarek, satysfakcję z pracy oraz zapobiega chęci odejścia z zawodu.

\section{Introduction}

The concept of the ethical climate of an organization/unit first appeared in the late 1980s as an expression of interest in the implementation of ethical principles as part of its daily functioning [1]. The ethical climate of an organization reflects the principles and guidelines relevant to that organization [2] and their correlation with the ethical consequences $[3,4]$. It is also described by Bell (2003) as a moral atmosphere pertaining to the social system and characterized by a common perception of good and evil, and assumptions about how moral concerns should be resolved [3]. Olson (1998), in turn, defines the ethical climate as "an organizational variable that can be managed and changed to improve the work environment" [5]. Cullen et al. (2003) argue that the ethical climate can serve as a perception lens for the personnel to diagnose and evaluate a situation [6]. In other words, it is a set of rules that promote specific behaviour among the organization's/unit's personnel. It also allows one to solve problems resulting from conflicts that are related, e.g., to professional duties or interpersonal tensions. Furthermore, it has an impact on whether the organization/unit personnel's decisions are made in accordance with ethical principles $[3,7]$. 
The ethical climate in healthcare encompasses both overt and covert values that affect the provision of healthcare and shape the workplace in which it is delivered. Thus, it serves as a variable that affects the work environment [8]. It is also defined as specific organizational conditions that facilitate discussion on patients' health problems and their different solutions, and provide a framework for ethical decisionmaking in the clinical environment $[3,9]$.

A positive ethical climate is characterised by a common vision of caring for work, in which the therapeutic team members inform and support each other, and which meets the needs of patients and their families [10]. It exerts a positive impact on stress management and job satisfaction $[3,10,11]$, as well as on the provided medical care [8]. The ethical climate among nurses has been described as their perception of ethical principles in their workplace [12]. The ethical climate may be influenced by cultural aspects, resulting in the adoption of varied ethical principles or values in different countries [11]. It also allows to learn about unethical behaviours and situations, and to take the necessary steps in order to eliminate them [13]. The ethical climate can therefore be regarded as a special dimension of the working climate [14].

The following research tools are useful in evaluating the hospital's ethical climate: the Ethical Climate Questionnaire (Victor \& Cullen 1988), the Ethical Climate Questionnaire (Cullen, Victor \& Bronson 1993), and the Hospital Ethical Climate Survey (Olson 1995) $[5,15]$.

The primary aim of this study is to analyse the available nursing research on the hospital's ethical climate conducted with the Hospital Ethical Climate Survey (HECS) research tool. The second aim is to analyse factors which correlate with the hospital ethical climate and are related to nurses' work.

A critical review of the literature available in 3 databases - PubMed, SCOPUS, and CINAHAL COMPLETE - was conducted in accordance with the following combination of keywords: ethical climate, hospital ethical climate survey, HECS, and nurses. The thematic synthesis included 37 articles (34 original research [1-8, 10-35] and 3 literature review [9, 36, 37]) from 1995 to 2021 addressing the issue of the ethical climate and its measurement.

\section{Characteristics of the tool}

The Hospital Ethical Climate Survey (HESC) was developed by Linda Olson in the United States in $1995[16,17]$. It was derived from the concept of ethical climate based on 2 theoretical models: Schneider's theory (1990) and Brown's theory (1990). Schneider's theory describes the organizational climate as the way employees perceive the procedures, regulations, and practices (both formal and informal) that are in place in the organization. Brown, on the other hand, stresses the importance of organizational conditions for employee engagement and ethical reflection based on 5 fundamental conditions: the possibility of disagreeing, the right to change one's opinion during consultations, the right to information, and the premise that all groups are involved in decision-making and encouraged to question certain solutions and debates $[5,18]$.

The questionnaire is used by nurses to assess the ethical climate in the hospital. It consists of 26 questions containing 5 subscales, with the following taken into consideration: relations with peers (questions 1,10 , 18,23 ), patients (questions $2,6,11,19$ ), managers (questions $3,7,12,15,20,24$ ), the hospital (questions 4, 8, 13, $16,21,25$ ), and physicians (question $5,9,14,17,22,26$ ). After reading the question, the respondent answers it using the 5-point Likert scale, where 1 means "almost never", and 5 means "almost always". The higher the value, the more favourable the ethical climate $[15,16]$.

The HESC validation was carried out in 3 stages. The questionnaire was first distributed among nurses who were asked to assess its content and transparency. Next, it was handed over to 30 nurses working in various hospital wards. At the final stage, 12 nurses employed in a hospital other than the original one received the HECS in order to verify, among other things, whether it was worded in a clear manner and to decide on the time needed to complete the questionnaire. Three hundred and sixty nurses from 2 large hospitals in the central-western USA participated in the proper test. The following criteria were used to qualify hospitals for the study: size, mission, type, and location. These were both non-profit and for-profit hospitals, and both these unit types had ethics committees in place. Originally, the HESC consisted of 74 questions, but this was reduced to 26 questions. The $\alpha$-Cronbach internal consistency and reliability coefficient for the HESC scale was 0.94. Taking into account each of the subscales, the $\alpha$-Cronbach coefficient was 0.73 for relationships with peers, 0.68 for patients, 0.92 for managers, 0.70 for the hospital, and 0.81 for relationships with physicians [5].

Cultural adaptations and validation of the Hospital's Ethical Climate Questionnaire have been performed in Iran ( $\alpha$-Cronbach 0.88), Belgium ( $\alpha$-Cronbach 0.91), Sweden ( $\alpha$-Cronbach 0.94), and Finland ( $\alpha$-Cronbach 0.90$)$, among others. It is also in the process of validation in Poland. The ethical climate was compared between private and public hospitals using the HECS questionnaire [15]. The studies were also carried out in psychiatric wards [1, 18], intensive care units [8], paediatric and neonatal wards [19], as well as during care of the elderly [20] and palliative care in the intensive care unit [21].

\section{Results}

The literature review reveals the impact of various factors on the perceptions of the ethical climate. A set 
of studies has shown the existence of a link between ethical climate and variables such as moral stress [21], job satisfaction $[3,22]$, and resignation and change of job $[23,24]$. Further HECS relationships with selected variables regarding nurses' work are presented below.

\section{Ethical climate and nurses' moral sensitivity}

The literature contains reports on the interdependence of the ethical climate and moral sensitivity. Cerit and Özveren (2019) conducted research at a university hospital in Turkey. The study sample consisted of nurses $(n=99)$, while the HECS and Moral Sensitivity Questionnaire (MSQ) were used as research tools. During face-to-face interviews, the highest HECS values were obtained in the "peers" $(15.46 \pm 3.69)$ and "patients" (15.38 \pm 3.70$)$ subscales, while the lowest were in the "hospital" subscale $(15.78 \pm 4.93)$. A significant and positive relationship between the hospital's ethical climate and moral sensitivity was also demonstrated $(r=0.565)$. The ethical climate of the hospital was assessed to be above average [25].

\section{Ethical climate and nurses' moral courage}

Taraz et al. (2019) [26] analysed the relationship between the ethical climate of the hospital and the moral courage of the nursing staff working in selected clinical hospitals in Iran. The study group consisted of 156 professionally active nurses with at least a bachelor's degree and 1 year's seniority. In the respondents' opinion, the ethical climate in their workplace was at an average level (mean: $3.79 \pm 0.56$ ). The highest results were obtained in the subscale regarding relations with peers (mean: $3.87 \pm 0.57$ ). The lowest scores were given to relationships with physicians (mean: $3.75 \pm 0.51$ ). Based on the results obtained, it was concluded that solutions should be developed to improve cooperation between nurses and physicians in order to ensure a high standard of healthcare. This study revealed a positive correlation between the hospital's ethical climate and the nurses' moral courage ( $p=0.001 ; r=0.92)$. Consequently, the higher the ethical climate among nursing staff, the more willing they are to demonstrate moral courage in making decisions and solving problems encountered in their work environment [26].

\section{Ethical climate and nurses' moral distress}

In their research, Saureland et al. (2014) aimed to assess the relationship between moral stress and the hospital's ethical climate. The study group consisted of 225 nurses working in intensive care units in an academic hospital with 600 beds. The research was conducted on-line using the hospital Intranet, and the ethical climate was measured with the use of the HECS. The nurses rated the level of the ethical climate as moderate $(94.39 \pm 18.3)$. The highest mean (4.18) was achieved by responses to statement 23: "safe pa- tient care is provided in my unit" (SD = 0.94), while the lowest score was given for statement 16: "conflict is openly dealt with, not avoided" (mean: $3.05 \pm 1.06$ ), which may suggest that the current ethical climate in this hospital is not sufficient to resolve conflicts and promote collaborative relationships. Nurses who provided care to adult patients also experienced moderate moral suffering (from $3.79 \pm 2.21$ to $2.14 \pm 2.42$ ) measured with the Moral Distress Scale (MDS) [8].

In their next article, Saureland et al. (2015) [19] described an on-line survey of 53 nurses working in neonatal and paediatric wards in an academic hospital. The aim of the study was to investigate moral distress (using MDS) and the ethical climate (using HECS). The average overall HECS score was 96.60 \pm 17.77 , while the total score ranged between 26 and 130 , indicating a moderately ethical work climate. As noted by the authors of the publication, the questions rated lowest in the HECS suggest that the hospital's ethical climate lacks conflict resolution, useful hospital policies, and managerial support in dealing with difficult patient care situations. On the other hand, the intensity of moral distress among nurses ranged from a low $0.11 \pm 0.38$ to a moderate $2.09 \pm 1.68$. A significant negative relationship between moral suffering and the ethical climate of the hospital was demonstrated, $r=-0.39, p<0.005$ [19].

Silén et al. (2011) [12] studied the relationship between moral stress (MDS) and the ethical climate (HECS) among nurses $(n=249)$ in Sweden. The level and frequency of moral stress was generally low, but it was high in situations where appropriate and safe care was not provided. It was found that the more positive the ethical climate, the rarer the situations related to moral stress [12].

Similar relationships were presented by Altaker (2018) [21]. The study was conducted on-line among 238 nurses from an intensive care unit, via the American Association of Critical Care Nurses (AACN) enewsletter. The Moral Distress Scale - Revised (MDS-R), HECS, and Psychological Empowerment Instrument (PEI) were used. That study showed, among other things, that a positive ethical climate is associated with lower levels of moral stress $(r=-0.354 ; p<0.001)$. A negative correlation was also found between moral stress and empowerment $(r=-0.145 ; p=0.02)$ [21].

Whitehead et al. (2015) [27] presented results in which moral stress was negatively correlated with an ethical work climate $(r=-0.516 ; p<0.001) .592$ clinicians participated in the study. The study revealed that nurses and other professionals involved in the direct care of the patient experienced higher moral suffering than physicians and other indirect care professionals $(p<0.001)$. Moreover, it was stressed that poor communication between groups of professionals constitutes the main source of moral distress, which correlates with the ethical climate of the workplace [27]. 
In turn, studies conducted by Bayat et al. (2019) [28] in selected hospitals of the Iranian Social Security Organization (ISSO) showed a positive hospital ethical climate (mean: 88.97). The study group consisted of 300 respondents. The lowest score in the HECS was awarded to responses to the statement: "In this hospital, nurses are supported and respected", and the highest score to the statement: "I have an appropriate working relationship with my colleagues". The lowest-rated subscales in HECS were those which concerned patients and peers, and the highest-rated were the "managers" subscales. No relationship between moral stress and the ethical climate of the hospital was demonstrated in the "managers" subscale, while the remaining subscales displayed a negative correlation [28].

\section{Ethical climate and nurses' job satisfaction, intent to change their workplace, and job burnout}

An interesting study was conducted by EstabariAsl et al. (2018) [29] in hospitals in Iran to investigate the relationship between the hospital's ethical climate (HECS) and job satisfaction (Minnesota Job Satisfaction Questionnaire) among 197 nurses working in the operating room. The ethical climate of the hospital was assessed by the majority of respondents as positive (the "peers", "managers", and "patients" subscales), and negative in the "physicians" and "hospital" subscales. It was shown that the hospital's ethical climate among nurses working in the operating room correlated significantly with job satisfaction [29].

Asgari et al. (2019) [30] studied the relationship between moral stress (MDS-R), ethical climate (HECS), and job satisfaction (Job Satisfaction Index) in critical care nurses $(n=142)$ working for the Iranian Social Security Organization (ISSO). The respondents assessed the ethical climate as positive $(3.51 \pm 0.53)$. A statistically significant relationship was found between the ethical climate and job satisfaction. The authors emphasize the importance of identifying ethical factors that cause stress in the workplace, their elimination, and improvement of the ethical climate resulting in increased job satisfaction and quality of care [30].

Research conducted by Joolaee et al. (2013) [3] using the HECS revealed a correlation between the ethical climate at work and job satisfaction $(r=0.39$, $p=0.001)$, i.e. the more positive the ethical climate, the higher the job satisfaction. The mean and standard deviation of HECS was $3.36 \pm 0.69$. The study sample consisted of nurses $(n=210)$ with a bachelor's or master's degree, working at Tehran University of Medical Sciences in the intensive care, surgical, cardiac, emergency, or internal medicine units. The authors pointed out that the hospital's executive staff should pay attention to the ethical climate prevalent in their organization and take actions to establish a code of ethics, distribute it among the personnel, and monitor and evaluate its deployment [3].

Allari (2016) [31] analysed the relationship between the ethical climate and variables such as job satisfaction and change of the workplace. The study group consisted of 150 active nurses working in hospitals in South Arabia. Ultimately, the ethical climate was rated at a moderate level (mean score: 3.30 ). The lowest result (2.12) was recorded for the responses to the statement: "Physicians ask nurses for their opinions about treatment decisions". This shows a barrier to communication between physicians and nurses, which contributes to the deterioration of the healthcare provided. The highest score (3.85) was obtained for the responses to the statement: "Safe patient care is given on my unit". Furthermore, a negative correlation $(r=-0.167)$ was observed between the ethical climate of the hospital and a change of the workplace. The nurses who positively assessed the ethical atmosphere at work did not intend to change their workplace. The research shows a strong correlation $(r=0.61)$ between the ethical climate and job satisfaction of the nursing staff, so the more positively the respondents assessed the ethical climate in their work environment, the more satisfied they were with their profession [31].

In a study involving 463 nurses from Missouri (USA), Hart (2005) [23] described the relationship between an unfavourable ethical climate and the personnel's intention to change their place of work. Accordingly, it was demonstrated that the ethical climate had a significant impact on one's willingness to move to another place of work. The ethical climate in the hospital served to explain $25.4 \%$ of the variance (variability) as regards intentions pertinent to job rotation (leaving the position currently held) and 14.7\% of the variance (variability) in intentions regarding change of the workplace (change of one's occupation) Rivaz et al. (2020) [32], wishing to determine the relationship between the ethical climate and professional burnout, conducted research among 212 nurses working in intensive care units (ICU) in hospitals in Iran. The data was collected using the HECS and MBI (Maslach Burnout Inventory). A positive ethical climate was found (3.5 \pm 0.6$)$, which also showed a significant, negative correlation with the frequency and intensity of professional burnout [32].

Asmaryadi et al. (2019) [22] analysed the impact of the ethical climate on the relationship between organizational justice and job satisfaction. The research took place at the University Teaching Hospital in Makassar, South Sulawesia in the emergency, intensive care, and neonatal intensive care units, the operating theatre, as well as outpatient clinics, the haemodialysis treatment room, and the chemotherapy treatment room, and included 133 nurses. The ethical climate was assessed using HECS (median: $78 \pm 6.01$ ). The results showed that the ethical climate played an 
important role in mediating the effect of organizational justice on job satisfaction. The ethical climate was also found to exert a direct and positive impact on job satisfaction. It was also found that $42.6 \%$ of nurses' job satisfaction is affected by organizational justice through the organization's ethical climate [22].

\section{Ethical climate and ethical leadership/ organizational citizenship behaviour of nurses}

Aloustani et al. (2020) [33] focused their deliberations on examining the relationship between ethical leadership, organizational citizenship behaviour (OCB) of nursing staff, and the ethical climate of the hospital. The study involved 250 nurses working in 1 of 12 university hospitals in Tehran between 2016 and 2017. A significant relationship between the ethical climate and the OCB of the nurses was observed $(p<0.001 ; r=0.61)$. The more favourable the atmosphere in the workplace, the more willing the staff were to manifest OCB. A link was also found between ethical leadership and the ethical climate $(p<0.001$; $r=0.65)$ in the healthcare facility. Ethical approaches to leadership have brought about closer cooperation between individual healthcare professionals, resulting in higher quality of patient care and more efficient work organization [33].

\section{Ethical climate and organizational support for nurses}

Studies by Khalesi et al. (2014) [17] showed that as far as problem solving is concerned there is a lack of support for medical personnel. Substandard cooperation of medical personnel and insufficient interaction between physicians and nurses can have a negative impact on the ethical climate. The study sample comprised 187 nurses working in 3 different hospitals in Tehran (Iran). The highest correlation was found between the subscales "hospital" and "physicians", while the lowest was between "hospital" and "managers". The overall ethical climate of Iranian hospitals was assessed to be 2.75 . The highest rating was awarded by the respondents to the "managers" (3.04) subscale, followed by "peers" (2.90), "patients" (2.80), "hospital" (2.61), and "physicians" (2.46). Khalesi et al. stated that in view of the role of the ethical climate in providing high-quality, safe care by medical personnel, strategies should be developed to improve communication between physicians and nurses [17].

\section{Ethical climate and nurses' professional} values and professional quality of life

Tehranineshat et al. (2020) [34] analysed the relationship between the ethical climate, professional values, and the quality of nurses' professional life. The study included 400 nurses from different units of an Iranian hospital. The total average rating for the ethi- cal climate was $100.09 \pm 17.11$, which indicates a satisfactory ethical atmosphere. The highest results were recorded in relations with managers $(23.33 \pm 0.20)$ and the lowest in relations with peers. Pearson's correlation coefficient demonstrated the presence of a significant relationship between nurses' professional values and ethical climate $(r=0.60 ; p<0.001)$. The surveyed members of nursing staff were therefore familiar with professional values and used them as a benchmark when making decisions on ethical issues. In addition, a significant relationship between the ethical climate, professional values, and the quality of nurses' professional life was established. Understanding the nurses' perception of professional values and improving ethical performance at work can help superiors develop more effective strategies for increasing job satisfaction and minimizing burnout and job-related stress [34].

\section{Ethical climate in public and private hospitals}

Ghorbani et al. (2014) [15] compared the ethical climate in private and public hospitals and examined the factors that affect it. The study involved 235 nurses from 3 private and 4 public hospitals in Sari, Iran. Compared to nurses from public hospitals, their colleagues employed in private hospitals $(3.82 \pm 0.61)$ perceived the hospital's ethical climate as more positive (3.76 \pm 0.54$)$; no statistically significant differences were found $(p=0.44)$. In private hospitals, as compared to public hospitals, in the "patients", "managers", "hospitals", and "physicians" subscales, a higher average score and standard deviation were obtained. Only in the "peers" subscale did the public hospitals record higher values than the private hospitals. In addition, statistical significance was demonstrated between HECS in public and private hospitals on the issues of managers ("Managers listen to me. My manager listens to me talk about patient care issues/problems"), patients ("The patients' wishes are respected"), and physicians ("Nurses and physicians trust one another"). In each of these issues the ethical climate in private hospitals was assessed more favourably. Working conditions had a significant impact on the perception of the ethical climate. A more favourable perception of the ethical work climate was recorded in the case of nurses in conditional employment than among those employed under different conditions in private hospitals $(F=4.48, p=0.01)$ and in the entire sample $(F=2.81, p=0.032)$. Demographic characteristics such as age, gender, level of education, and professional seniority did not influence the assessments of the ethical climate [15].

\section{Ethical climate in different clinical environments}

Suhonen et al. (2013) [20] studied the prevailing ethical climate, the work practice environment, as well as the level of perceived personalised care among 
nursing staff in care facilities for the elderly in southern Finland. The study group consisted of 874 nurses. The ethical climate was assessed by the staff as moderate (mean: $3.85 \pm 0.55$ ). The highest score was awarded to the ethical climate in residential homes with assistance, followed by nursing homes, municipal health centre hospitals, and specialized acute medical care hospitals $(p=0.06)$. The study showed a correlation between the ethical climate, work practice environment, and the standard of perceived personalised care. The results obtained showed that a more favourable evaluation of the ethical climate and work practice environment is accompanied by a higher rating of the individualised care provided [20].

In their study, Pergert et al. (2019) addressed the ethical climate in paediatric oncology wards in 6 university hospitals in Sweden. The study covered physicians and nurses $(n=278)$ participating in the process of treatment of children with oncological diseases. Differences in the perception of the ethical climate between the different professional groups were found. Compared to nursing staff, physicians perceive the ethical climate at work as more satisfactory, having recorded higher scores for 12 out of 21 positions in the HECS questionnaire [35].

The ethical climate of the hospital is particularly important in the psychiatric ward. HESC was first used in such a ward by Claeys et al. (2014) in Belgium (Flanders) in 2009. 265 nurses took part in the study. In the course of the research, it was noted that work at this department required multidisciplinary cooperation, so HESC was translated and expanded to include an element on paramedics and mutual interactions with other disciplines. Three questions were added regarding, e.g., mutual respect and trust in relation to the paramedic in the "physicians" subscale. The hospital was characterized by a positive ethical climate (mean: $3.85 \pm 0.46$ ) [18].

In their work, Hajibabaee et al. (2016) pointed to the role of education administered, e.g. through programs and academic courses, which also defines, among other things, the objectives and functions of the hospital/clinical ethics committee, such as providing ethical education to medical personnel, developing strategies to prevent future ethical problems, providing moral support to personnel, and organizing meetings with other ethics committees in order to exchange experiences and actions and to evaluate the committees' results accordingly. It should be emphasized that the authors in 18 countries searched for references of the ethical climate to clinical practice [36]. Weistein (2002) pointed out that the hospital should create an ethical climate and devise methods for dealing with violations of ethical principles. The author recognized the importance of applying detailed rules, procedures, and programs, and of there being an ethics committee in place at the hospital [37].

\section{Conclusions}

Analysis of available research results show that HECS is a credible and reliable research tool used in research on the ethical climate in hospitals. The HECS makes it possible to monitor and assess elements of organisation climate and how they influence nursing professional performance. This in turn helps nursing managers to develop and implement appropriate strategies to promote better working conditions for nurses, improve their job satisfaction, and prevent intent to change their workplace. Such strategies are of great importance in the time of a shortage of nurses, and moreover, it also influence the quality of provided nursing care.

\section{Conflict of interest}

The authors declare no conflict of interest.

\section{References}

1. Silén M, Haglund K, Hansson MG, Ramklint M. Ethics rounds do not improve the handling of ethical issues by psychiatric staff. Nord J Psychiatry 2015; 69: 1700-1707.

2. Noh YG, Jung MS. Path analysis of the influence of hospital ethical climate perceived by nurses on supervisor trust and organizational effectiveness. J Korean Acad Nurs 2016; 46: 824-835.

3. Joolaee S, Jalili HR, Rafii F, Hajibabaee F, Haghani H. The relationship between ethical climate at work and job satisfaction among nurses in Tehran. Indian J Med Ethics 2013; 10: 238-242.

4. Bell SE. Ethical climate in managed care organizations. Nurs Adm Q 2003; 27: 133-139.

5. Olson L. Hospital nurses' perception of ethical climate of their work setting. Image J Nurs Sch 1998; 30: 345-349.

6. Cullen JB, Parboteeah KP, Victor B. The effects of ethical climates on organizational commitment: a two-study analysis. J Bus Ethics 2003; 46: 127-141.

7. Joolaee S, Jalili HR, Rafii F, Hajibabaee F, Haghani H. Relationship between moral distress and job satisfaction among nurses of Tehran University of Medical Sciences Hospitals. Hayat 2012; 18: 42-51.

8. Saureland J, Marotta K, Peinemann MA, Berndt A, Robichaux $\mathrm{C}$. Assesing and adressing moral distress and ethical climate, part I. Dimens Crit Care Nurs 2014; 33: 234-245.

9. Schluter J, Winch S, Holzhauser K, Henderson A. Nurses' moral sensitivity and hospital ethical climate. Nurs Ethics 2008; 15: 304-321.

10. Pergert P, Bartholdsom C, Wenemark M, Lutzen K, Sandeberg M. Translating and culturally adapting the shortened version of the Hospital Ethical Climate Survey (HECS-S) - retaining or modifying validated instruments. BMC Med Ethics 2018; 19: 35.

11. Borhani F, Jalali T, Abbaszadeh A, Haghdoost AA, Amiresmaili M. Nurses' perception of ethical climate and job satisfaction. J Med Ethics Hist Med 2012; 5: 6.

12. Silén M, Svantesson M, Kjellström S, Sidenvall B, Christensson L. Moral distress and ethical climate in a Swedish nursing context: perceptions and instrument usability. J Clin Nurs 2011; 20: 3483-3493. 
13. Aydan S, Kaya S. Ethical climate as a moderator between organizational trust \& whistle-blowing among nurses and secretaries. Pakistan J Med Sci 2018; 34: 429-434.

14. Munir Y, Ghafoor MM, Rasil A. Perception of ethical climate and turnover intention among nursing staff: does organizational cynicism mediate? Int J Hum Rights Healthc 2018; 11: 319-332.

15. Ghorbani A, Hesamzadeh A, Khademloo M, Khalili S, Hesamzadeh S, Berger V. Public and private hospital nurses' perceptions of the ethical climate in their work settings, Sari City, 2011. Nurs Midwifery Stud 2014; 3: e12867.

16. Olson LL. Ethical climate in health care organizations. Int Nurs Rev 1995; 42: 85-90.

17. Khalesi N, Arabloo J, Khosravizadeh O, Taghizadeh S, Heyrani A, Ebrahimian A. Psychometric properties of the Persian version of the "Hospital Ethical Climate Survey". J Med Ethics Hist Med 2014; 7: 15.

18. Claeys M, Faelens A, Sabbe, BG, Schrijvers, D, Dierckx De Casterlé, B, Luyten P. Psychometrische kwaliteiten van de Hospital Ethical Climate Survey: een cross-sectionele studie bij Belgische psychiatrische verpleegkundigen. Tijdschrift voor Psychiatrie 2014; 56: 778-787.

19. Saureland J, Marotta K, Peinemann MA, Berndt A, Robichaux $\mathrm{C}$. Assesing and adressing moral distress and ethical climate, part II. Dimens Crit Care Nurs 2015; 34: 33-46.

20. Suhonen R, Stolt M, Gustafsson ML, Katajisto J, Charalambous $\mathrm{A}$. The associations among the ethical climate, the professional practice environment and individualized care in care settings for older people. J Adv Nurs 2013; 10: 1356-1368

21. Altaker KW. Relationships among palliative care, ethical climate, empowerment, and moral distress in intensive care unit nurses. Am J Criti Care 2018; 27: 295-302.

22. Asmaryadi, Pasinringi SA, Muis M, Indahwaty Sidin A, Irwandy. Mediating effect of ethical climate on the relationship between organizational justice and job satisfaction. EAS J Psychol Behav Sci 2019; 1: 114-118.

23. Hart SE. Hospital ethical climates and registered nurses' turnover intentions. J Nurs Scholarsh 2005; 37: 173-177.

24. Tei-Tominaga $M$, Nakanishi $M$. The influence of supportive and ethical work environments on work-related accidents, injuries, and serious psychological distress among hospital nurses. Int J Environ Res Public Health 2018; 15: 240.

25. Cerit B, Özveren H. Effect of hospital ethical climate on the nurses' moral Sensitivity. Eur Res J 2019; 5: 282-290.

26. Taraz Z, Loghmani L, Abbaszadeh A, Ahmadi F, Safavibiat Z, Borhani F. The relationship between ethical climate of hospital and moral courage of nursing staff. Electron J Gen Med 2019; 16: 109.

27. Whitehead PB, Herbertson RK, Hamric AB, Epstein EG, Fisher JM. Moral distress among healthcare professionals: report of an institution-wide survey. J Nurs Scholarsh 2015; 47: 117-125.

28. Bayat M, Shahriari M, Keshvari M. The relationship between moral distress in nurses and ethical climate in selected hospitals of the Iranian social security organization. J Med Ethics Hist 2019; 12: 8.

29. Etebari-Asl Z, Abdollahzadeh F, Lotfi M. The relationship of ethical climate and nurses' job satisfaction in the operating room: a cross-sectional study. Nurs Midwifery Stud 2017; 6: 137-139.

30. Asgari S, Shafipour V, Taraghi Z, Yazdani-Charati J. Relationship between moral distress and ethical climate with job satisfaction in nurses. Nurs Ethics 2019; 26: 346-356.
31. Allari R. The relationship between hospital ethical climate, job satisfaction, and intent to turnover among nurses. Merit Res J Med Med Sci 2016; 4: 392-398.

32. Rivaz M, Asadi F, Mansouri P. Assessment of the relationship between nurses' perception of ethical climate and job burnout in intensive care units. Invest Educ Enferm 2020; 38:e12.

33. Aloustani S, Atashzadeh-Shoorideh F, Zagheri-Tafreshi M, Nasiri M, Barkhordari-Sharifabad M, Skerrett V. Association between ethical leadership, ethical climate and organizational citizenship behavior from nurses' perspective: a descriptive correlational study. BMC Nursing 2020; 19: 15.

34. Tehranineshat B, Torabizadeh C, Bijani M. A study of the relationship between professional values and ethical climate and nurses' professional quality of life. I J Nurs Sci 2020; 7: 313-319.

35. Pergert P, Bartholdson C, Sandeberg M. The ethical climate in paediatric oncology - a national cross-sectional survey of health-care personnel. Psychooncology 2019; 28: 735-741.

36. Hajibabaee F, Joolaee S, Cheraghi MA, Salari P, Rodney P. Hospital/clinical ethics committees' notion: an overview. J Med Ethics Hist Med 2016; 9: 17.

37. Weinstein HC. Ethics Issues in Security Hospitals. Behav Sci Law 2002; 20: 443-461.

\section{Address for correspondence:}

\section{Magdalena Dziurka}

Department of Management in Nursing

Faculty of Health Sciences

Medical University of Lublin

Lublin, Poland

E-mail: md.dziurka@gmail.com 